\title{
APPLIED GEOCHEMISTRY IN THE TWENTY-FIRST CENTURY: MINERAL EXPLORATION AND ENVIRONMENTAL SURVEYS*
}

\section{A. DEMETRIADES ${ }^{1}$}

\section{ABSTRACT}

Applied (exploration and environmental) geochemistry in the twentieth century is briefly reviewed, and its future developments in the twenty-first century are envisaged in the light of advances in analytical instruments (laboratory and field) and computer technology. It is concluded that applied geochemical methods must be used by well-trained applied geochemists, and the potential for future developments is limited only by their ingenuity.

KEY WORDS: Applied geochemistry, exploration geochemistry, environmental geochemistry, mineral exploration, analytical methods

\section{INTRODUCTION}

Modern geochemistry begins with the development of chemistry, and the scientific understanding of the relationship between chemistry and mineralogy. J.J. Berzelius (1779-1848), the famous Swedish chemist, called, in 1821, mineralogy the chemistry of the Earth's crust. G. Bischof (1792-1870) published a series of lectures, given from 1845-1859, under the title "Elements of Chemical and Physical Geology". In fact, he was the first to introduce chemistry, in a systematic manner, into geology. However, C.F. Schpnbein (1799-1869), professor of chemistry at Basle, was the first to use in 1838 the word "Geochemie", forecasting, therefore, the future birth of a new science, "geochemistry".

A more detailed account of the history of geochemistry and its founders will be found in Rankama and Sahama (1950), Mason (1966), Goldschmidt (1970), Wedepohl (1969) and Fairbridge (1972). It is herein briefly mentioned that the Russian scientist, V. Vernadsky (1863-1945), studied the world-wide distribution of In, Tl, $\mathrm{Ga}, \mathrm{Rb}$ and $\mathrm{Cs}$, and laid down the principles of biogeochemistry; his greatest work, "The Biosphere", published in Russian in 1926, has only recently become available in English (Vernadsky, 1998). Another Russian, A.E. Fersman (1883-1945), focused his research activities in the geochemistry of the lithosphere. F.W. Clarke (18471931), an American, came to the forefront of geochemistry with his famous book on "The Data of Geochemistry", published in 1908. Finally, V.M. Goldschmidt's (1888-1947) book on "Geochemistry", published in 1954 after his death, was the first systematic work on geochemical principles governing the distribution of elements in the earth's crust (Goldschmidt, 1970). Rankama and Sahama written the second systematic work on "Geochemistry" in 1950. Another classic researcher on geochemistry is Brian Mason (1966), whose textbook on the "Principles of Geochemistry" has been one of the most recommended, and widely used, textbooks for undergraduate students since 1952 .

One of the monumental reference works on geochemistry is the "Handbook of Geochemistry" edited by K.H. Wedepohl (1969-1978), where geochemical information is presented in six volumes. Rhodes Fairbridge (1972) edited another excellent publication, "The Encyclopedia of Geochemistry and Environmental Sciences". Finally, the twentieth century ends with the "Encyclopedia of Geochemistry" edited by Marshall and Fairbridge (1999), which is an exceptional reference work for earth scientists and environmentalists alike.

Although geochemistry draws on mineralogy, petrology, chemistry and geology, it has existed and developed as a separate scientific discipline in its own right since the time of Schpnbein. Applied Geochemistry is the natural extension of geochemistry, and it is concerned with the application of geochemical principles for the location and delineation of natural mineral resources, and the conservation of the environment and health (Siegel, 1974). Applied geochemistry has been subdivided into two market-oriented branches: (a) in Mineral Exploration is called "Exploration Geochemistry", and (b) in environmental sciences is known as "Environ-

\footnotetext{
* APPLIED GEOCHEMISTRY IN THE TWENTY-FIRST CENTURY: MINERAL EXPLORATION AND ENVIRONMENTAL SURVEYS -

1. Institute of Geology and Mineral Exploration, 70 Messoghion Street, Gr-115 27 Athens, Greece.
} 
Table 1. Comparison between Exploration and Environmental Geochemistry (modified from Huang, 1991).

\begin{tabular}{|c|c|c|}
\hline Variable & Exploration Geochemistry & Environmental Geochemistry \\
\hline $\begin{array}{l}\text { Subject of } \\
\text { investigation }\end{array}$ & $\begin{array}{l}\text { Lithosphere, hydrosphere, biosphere, } \\
\text { atmosphere }\end{array}$ & $\begin{array}{l}\text { Lithosphere, hydrosphere, biosphere, } \\
\text { atmosphere }\end{array}$ \\
\hline Sample media & $\begin{array}{l}\text { Stream sediment, flood-plain sediment, } \\
\text { soil, water, vapour, plants, microbes, } \\
\text { rocks }\end{array}$ & $\begin{array}{l}\text { Stream sediment, flood-plain sediment, } \\
\text { soil, water, vapour, plants, microbes, } \\
\text { rocks (aquifers) }\end{array}$ \\
\hline $\begin{array}{l}\text { Major } \\
\text { analytical } \\
\text { tools }\end{array}$ & $\begin{array}{l}\text { Atomic absorption, ICP, XRF, mass } \\
\text { spectrometer, portable GC/MS, portable } \\
\text { gas sniffers, portable scintillometer, } \\
\text { pH-meter, Eh-meter, conductivity meter }\end{array}$ & $\begin{array}{l}\text { Atomic absorption, ICP, XRF, mass } \\
\text { spectrometer, portable GC/MS, portable } \\
\text { gas sniffers, portable scintillometer, } \\
\text { pH-meter, Eh-meter, conductivity meter }\end{array}$ \\
\hline $\begin{array}{l}\text { Data treatment } \\
\text { tools/aids }\end{array}$ & $\begin{array}{l}\text { Databases, statistical software, } \\
\text { kriging, contouring software }\end{array}$ & $\begin{array}{l}\text { Databases, statistical software, } \\
\text { kriging, contouring software }\end{array}$ \\
\hline Employers & Mining companies, government & $\begin{array}{l}\text { Government, consulting environmental } \\
\text { firms }\end{array}$ \\
\hline History & $\begin{array}{l}\text { Started in } 1930^{\prime} s \text {; boomed with the } \\
\text { advent of AAS and ICP in the } 1960^{\prime} \mathrm{s} \text { \& } \\
1970^{\prime} \mathrm{s}\end{array}$ & $\begin{array}{l}\text { Started in the } 1960^{\prime} \mathrm{s} ; \text { boomed with } \\
\text { increased environmental awareness plus } \\
\text { environmental laws in the } 1970^{\prime} \mathrm{s}\end{array}$ \\
\hline
\end{tabular}

mental Geochemistry" (Demetriades et al., 1997). Table 1 shows that the applied geochemical methods used in both branches are the same, and only the end-users differ. In fact, exploration geochemists, over the last sixty years, have developed methods that are applicable to environmental investigations, and often work with environmentally significant data in pursuit of the mineral discovery.

In this paper, the achievements of Applied Geochemistry in the twentieth century will be briefly reviewed and, subsequently, its expected developments in the twenty-first century.

\section{APPLIED GEOCHEMISTRY IN THE TWENTIETH CENTURY}

\subsection{Exploration Geochemistry}

The first known systematic geochemical prospecting programme appears to have been carried out in the U.S.S.R. in 1932 (Rattigan, 1970; Bradshaw et al., 1972). The period from 1940 to 1957 witnessed an unprecedented scale of activity in mineral exploration, and the development of geochemical prospecting methods (Hawkes and Webb, 1962). Historical reviews of the development of exploration geochemistry have been given by Hawkes and Webb (1962), Boyle (1967), Boyle and Garrett (1970), Hawkes (1976) and Govett (1986).

Geochemical prospecting techniques are now recognised as important in mineral exploration as the traditional geological and geophysical methods. The basic principle of geochemical prospecting is that the emplacement of a mineral deposit causes an anomalous dispersion pattern of an indicator element or elements (pathfinders) in the rocks surrounding the ore deposit or after its emplacement. In mineral exploration, such a dispersion pattern offers a target that is larger than the actual mineral deposit, and, which may be detectable in superficial materials overlying a concealed deposit. Materials systematically sampled are rocks, soils, stream sediments, waters, and gases. These are afterwards analysed by semi-quantitative or quantitative chemical methods. The resulting geochemical data when examined in relation to "background" levels of element concentrations, typical of the material being analysed, may reveal "anomalous" dispersion patterns by which the location, size and mineral associations of a concealed mineral deposit may be inferred.

Geochemical prospecting techniques may be applied on any scale, and at any stage of the mineral exploration programme (Table 2). Geochemical survey methods that have been used successfully in mineral exploration are described in text books by Ginzburg (1960), Hawkes and Webb (1962), Bradshaw et al. (1972), Siegel (1974), Levinson (1974, 1980), Joyce (1976), Beus and Grigorian (1977), Rose et al. (1979), Fletcher et al. (1986) and Levinson et al. (1987). The state-of-the-art of applied geochemical methods is described in a sevenvolume series under the title "Handbook of Exploration Geochemistry" edited by Gerry J.S. Govett (Fletcher, 1981; Howarth, 1983; Govett, 1983; Butt and Zeegers, 1992; Kauranne et al., 1992; Hale and Plant, 1994; Hale, 2000).

Case histories and the successful application of geochemical prospecting methods can be found in the following journals: "Journal of Geochemical Exploration" and "Applied Geochemistry", and as from 2001 in "Geochemistry:

Exploration, Environment, Analysis". Exploration geochemistry papers can also be found in other mineral exploration and economic geology journals, such as "Economic Geology", "Transactions of the Institution of Mining and Metallurgy, Section B: Applied Earth Science". 
Table 2. The role of geochemical prospecting in a phased mineral exploration programme for the location of metalliferous deposits (modified from Rattigan, 1970, Table 1, p.74).

\begin{tabular}{|c|c|c|c|}
\hline $\begin{array}{c}\text { Stage in } \\
\text { programme }\end{array}$ & Purpose & Geochemical survey work & $\begin{array}{c}\text { Other concurrent } \\
\text { exploration activities }\end{array}$ \\
\hline Preliminary & $\begin{array}{l}\text { To select media, indica- } \\
\text { tors (pathfinders) and } \\
\text { analytical techniques. }\end{array}$ & $\begin{array}{l}\text { Literature survey of local } \\
\text { terrain and geochemical } \\
\text { techniques. }\end{array}$ & \multirow{2}{*}{$\begin{array}{l}\text { 1. Collation of geological } \\
\text { data. } \\
\text { 2. Photogeological } \\
\text { interpretation and base } \\
\text { map preparation. } \\
\text { 3. Planning of field opera- } \\
\text { tions, equipment, staf- } \\
\text { fing, transportation. }\end{array}$} \\
\hline Orientation & $\begin{array}{l}\text { To test the suitability of } \\
\text { chosen techniques in field } \\
\text { conditions and modify as } \\
\text { necessary to accord with a } \\
\text { systematic field program- } \\
\text { me; to determine "back- } \\
\text { ground" and "threshold" } \\
\text { values for different } \\
\text { media. }\end{array}$ & $\begin{array}{l}\text { Reconnaissance geochemical } \\
\text { testing of different } \\
\text { sample media in mineral- } \\
\text { ised and non-mineralised } \\
\text { country. Detailed geoche- } \\
\text { mical testing over known } \\
\text { mineral deposits. }\end{array}$ & \\
\hline $\begin{array}{l}\text { Regional } \\
\text { field survey }\end{array}$ & $\begin{array}{l}\text { To reduce large prospect- } \\
\text { ing areas to small anoma- } \\
\text { lous target areas. }\end{array}$ & $\begin{array}{l}\text { Regional stream sediment } \\
\text { survey, and widespread } \\
\text { geochemical testing of } \\
\text { rocks, soils, or stream/ } \\
\text { spring waters. }\end{array}$ & $\begin{array}{l}\text { 1. Airborne geophysics (ra- } \\
\text { diometric, magnetic, } \\
\text { electromagnetic). } \\
\text { 2. Regional geological map- } \\
\text { ping. }\end{array}$ \\
\hline $\begin{array}{l}\text { Detailed } \\
\text { field survey }\end{array}$ & $\begin{array}{l}\text { To evaluate the signifi- } \\
\text { cance of anomalous targets } \\
\text { indicated by any explora- } \\
\text { tion tools, and to predict } \\
\text { the locus of an ore depo- } \\
\text { sit for test excavations } \\
\text { or drilling. }\end{array}$ & $\begin{array}{l}\text { Detailed systematic geo- } \\
\text { chemical survey to a } \\
\text { close-spaced grid. Inter- } \\
\text { pretation of dispersion } \\
\text { patterns. }\end{array}$ & $\begin{array}{l}\text { 1. Ground geophysics. } \\
\text { 2. Detailed geological map- } \\
\text { ping to determine ore } \\
\text { loci. }\end{array}$ \\
\hline $\begin{array}{l}\text { Testing and } \\
\text { proving }\end{array}$ & $\begin{array}{l}\text { To acquire information on } \\
\text { ore localisation, \& wall- } \\
\text { rock effects; structure } \\
\text { and stratigraphic correla- } \\
\text { tion. }\end{array}$ & $\begin{array}{l}\text { Geochemical testing of } \\
\text { drill-core or cuttings; } \\
\text { borehole probing. }\end{array}$ & $\begin{array}{l}\text { 1. Geophysical core log- } \\
\text { ging. } \\
\text { 2. Geological core logging. }\end{array}$ \\
\hline
\end{tabular}

During the last sixty years, geochemical prospecting methods have evolved from semi-quantitative to quantitative, from the analysis of a single or a few elements to tens of elements. In the 1940's and early 1950 's the objective was to prove to industry that geochemical prospecting methods can be used effectively in the search for mineral deposits. Hence, practical and cost-effective methods that could be used in the field were developed. This pioneering effort is ascribed to John Webb, the founder of the famous Applied Geochemistry Research Group of the Royal School of Mines at Imperial College (University of London), and Herbert Hawkes, Geochemical Prospecting Unit of the U.S. Geological Survey. Stanton (1966) described the semi-quantitative colorimetric methods used in the field.

The advent of atomic absorption spectrophotometry (AAS) in the late 1950's, and its establishment in the 1960's, resulted in the multi-element analysis of geological materials (Stanton, 1976; Angino and Billings, 1972). Other multi-element methods used were emission spectrometry and X-ray fluorescence (XRF) (Stanton, 1976). Modern XRF with computer-controlled operation and matrix correction is nowadays a powerful multi-element analytical tool. In the last twenty years computer-controlled inductively-coupled plasma atomic emission spectrometry (ICP-AES) has given a new impetus in the simultaneous multi-element analysis of geological materials. Finally, in the last ten years the computer-controlled inductively-coupled plasma mass spectrometer (ICP-MS) has opened new horizons in multi-element and isotopic analysis.

High technology has enabled the development of portable analytical instruments, such as XRF and spectrometers, for the analysis of geological materials and water in the field. These instruments, together with global positioning systems (GPS) for locating the sample site, and powerful laptop computers and colour inkjet printers, offer the applied geochemist the opportunity to carry out cost-effective multi-element determinations in the field, and the processing of data at the site being investigated.

It is quite apparent that the sensitivity and precision of analytical geochemical methods has improved considerably with the gradual utilisation of advanced instrumental techniques.

As is pointed out by Govett (1986) the analytical improvements will continue to occur and, therefore, it is significant that exploration geochemists ensure that

(a) the physical size of the initial sample is adequate to provide a representative sample of the constituent of interest, and

(b) subsequent sample treatment in terms of size reduction, concentration and specific components, and ultimate aliquot for analysis are designed to meet the capabilities of the analytical technique and nature of 
occurrence of the component of interest (Fletcher, 1981; Govett, 1983).

Further, the sensitivity of advanced instrumental analytical techniques means that more stringent quality control procedures must be applied in order to obtain data of high integrity.

Exploration geochemists realised in the early stages of development of sampling and analytical methods that quality assurance and control procedures in any geochemical sampling and analytical programme are very significant for securing the integrity and validity of data (Fletcher, 1981). They are, therefore, able to produce data of high integrity for use in applied geochemical investigations, including environmental impact assessment studies (Demetriades et al., 1997).

In the last sixty years, a dramatic change has also taken place in the handling of geochemical data. In the early days, statistical graphical techniques and plotting of geochemical maps were carried out by hand (Tennant and White, 1959; Lepeltier, 1969; Sinclair, 1974; Howarth, 1983). The first innovation was a desk-calculator, which permitted the computation of standard deviation or analysis of variance on small data sets. Since, the 1960's mainframe computers and colour-plotters enabled the statistical processing and map plotting of large data sets. During the last twenty years, the development of high-speed desktop and laptop computers allow the electronic data storage, and interactive statistical treatment and colour-map plotting of multi-element data sets that were unthinkable a few decades ago. Hence, the applied geochemist is able to manipulate his data with the aid of interactive user-oriented software for population splitting (Stanley, 1987), computing simple ratios to discriminant, cluster, factor and exploration data analysis, and to plot colour geochemical distribution maps using complex geostatistical techniques, such as variograms and kriging (Davis, 1973; Howarth, 1983).

A significant achievement of applied geochemistry was the publication of multi-purpose geochemical atlases. The Applied Geochemistry Research Group at Imperial College (Webb et al., 1978) compiled the first multi-element atlas, the "Wolfson Geochemical Atlas of England and Wales". This was followed by others published by the Geological Surveys of Austria, Britain, Estonia, Finland, Germany, Lithuania, Norway, Poland, Slovakia, etc. The next step was the publication of digital atlases. The British Geological Survey was the first to include on a CD-rom the geochemical atlas of the Lake District (Green et al., 1997). Subsequently, the USGS published the digital National Geochemical Atlas of the Conterminous United States (Grossman, 1998), and Niedersøchsisches Landesampt fór Bodenforschung the "Digitaler atlas Hintergrundwerte" (NLFB, 2000).

Finally, the twentieth century ends with the commencement of the "Global Geochemical Baselines" project, the aim of which is the compilation of the global geochemical reference network, using the same methods of sampling (residual soil, active stream sediment, overbank sediment, flood-plain sediment and stream water), sample preparation, analysis and data treatment (Darnley, 1990, 1995; Darnley et al., 1995; B $\psi$ lviken et al., 1996; Demetriades, 1998; Plant et al., 1996, 1997; Salminen et al., 1998). The European part of the project has started in 1998, and the first results are expected in 2002.

\subsection{Environmental Geochemistry}

Environmental geochemistry started in the early 1960 's, because there was a growing awareness of relationships between the distribution of trace elements in the surface environment and health in plants, animals and human beings. The first multidisciplinary team in this field in the World, comprised from geochemists, chemists, soil scientists, water engineers, veterinary scientists and medical practitioners, investigated an unusual incidence of cancer in part of south-west England (Webb, 1983). Showing, therefore, the complexity of environmental problems, and the need for close collaboration of scientists from different disciplines in order to find viable solutions. Applied environmental geochemistry has grown enormously during the last forty years, and it encompasses the many factors influencing the sources, dispersion and distribution of elements in the environment, their pathways into foodstuffs and water supplies, and possible effects on health and disease in plants, animals and humans.

Environmental geochemistry employs exactly the same methods of sampling, sample preparation, analysis and data processing as used by exploration geochemistry (Table 1). The differences being in the more rigorous quality assurance/quality control procedures used for the generation of environmental compared to exploration data (Runnells, 1993), and the end-user (Huang, 1991).

Case histories and the successful application of applied environmental geochemistry can be found in the journals of "Environmental Geochemistry and Health" and "Applied Geochemistry", and as from 2001 in "Geochemistry: Exploration, Environment, Analysis". Environmental geochemistry papers can also be found in special issues of the "Journal of the Geological Society", and books published by the Geological Society of London, and other publishers (Thornton, 1983, 1988; Thornton and Culbard, 1987; Hemphill and Cothern, 1989; 
Fergusson, 1990; Appleton et al., 1996; Lerner and Walton, 1998; Chappell et al., 1999).

\section{APPLIED GEOCHEMISTRY IN THE TWENTY-FIRST CENTURY}

During the twentieth century applied geochemistry has grown from an empirical to a fundamental science with principles, and sound purposes, serving in the one hand the mining industry in the mineral exploration effort, and on the other human kind in the sustainable development of our planet earth. Twentieth century applied geochemists leave a very large legacy to their twenty-first century counterparts. The European results of the "Global Geochemical Baselines" project will be available in 2004 and, provided funds are made available, the whole globe could be covered by the year 2010. Thus, for the first time scientists, policy-makers and other interested parties will have a unified multi-element global geochemical database, from which they can draw information and conclusions about the surface chemistry of our planet earth.

Analytical improvements will continue to occur, as more sophisticated and sensitive laboratory and portable instruments become available. These will offer the applied geochemist the opportunity to study in detail the distribution of chemical elements in relation to rock forming minerals, and ore-forming processes. Interactive user-oriented software and powerful desktop and laptop computers will help enormously the applied geochemist in the interpretation of data, and refinement of geochemical models for studying the dispersion in water and soil of anthropogenic contaminants, and for the detection of blind ore deposits. The latter challenge can only be realised if drill-core is analysed in the field by portable laser plasma spectrographs, and results downloaded directly to powerful laptop computers with plotting and printing peripherals.

Twenty-first century applied geochemists will undoubtedly have a considerable amount of data to process, and through the World Wide Web and electronic mail, extensive information and assistance for the solution of technical problems. Hence, the future depends largely to their imagination and resourcefulness.

\section{CONCLUSION}

The conclusions are drawn from a paper written by Gerry Govett (1986), a geochemist with great foresight, and as a tribute to his pioneering work in Greece in 1971. The apparent simplicity of applied geochemistry is both its great merit and its greatest disadvantage. The basic geochemical principles are indeed simple, and lead the unwary and untrained scientists into the erroneous belief that uncritical collection of samples, analysis and subsequent examination of results (or, worse, uncritical submission of data to computer treatment) will lead to instant recognition of anomalous geochemical patterns. When the result is either a multitude of anomalies or none, or a false anomaly is drilled, discontent sets in, and geochemistry is abandoned as an exploration tool. The solution to this particular problem is training of professional applied geochemists. The need for training is increasing as more and more subtle anomalies are sought to detect concealed and more deeply buried mineralisation, but also in the interpretation of anthropogenic contamination.

The potential for the future is limited only by the ingenuity of applied geochemists. There must be an accelerated research effort into geochemical processes, and a determined attempt to quantify geochemical responses. Applied geochemists must continue to be fearless innovators, and willing to try everything, even if pure science dictates that it cannot work. Brilliant fundamental research must, therefore, be matched by well planned "imaginative empirical" studies.

\section{ACKNOWLEDGEMENTS}

The paper is published by permission of the General Director of the Hellenic Institute of Geology and Mineral Exploration (IGME).

\section{REFERENCES}

ANGINO, E.E. AND BILLINGS, G.K., 1972. Atomic absorption spectrometry in geology. Elsevier Publishing Co., Amsterdam, $191 \mathrm{pp}$.

APPLETON, J.D., FUGE, R. AND MCCALL, G.J.H. (Editors), 1996. Environmental geochemistry and health with special reference to developing countries. The Geological Society, London, $264 \mathrm{pp}$.

BEUS, A.A. AND GRIGORIAN, S.V., 1977. Geochemical exploration methods for mineral deposits. Applied Publishing Ltd., Wilmette, Illinois, 287 pp.

BØLVIKEN, B., BOGEN, J., DEMETRIADES, A., DE VOS, W., EBBING, J., HINDEL, R., LANGEDAL, M., LOCUTURA, J., O'CONNOR, P., OTTESEN, R.T., PULKKINEN, E., SALMINEN, R., SCHERMANN, O., 
SWENNEN, R., VAN DER SLUYS, J. AND VOLDEN, T., 1996. Regional geochemical mapping of Western Europe towards the year 2000. J. Geochem. Explor., 56: 141-166.

BOYLE, R.W., 1967. Geochemical prospecting - retrospect and prospect. Can. Inst. Min. Metall. Bull., 60 (657): 44-49.

BOYLE, R.W. AND GARRETT, R.G., 1970. Geochemical prospecting - a review of its status and future. EarthScience Reviews, 6: 51-75.

BRADSHAW, P.M.D., CLEWS, D.R. AND WALKER, J.L., 1972. Exploration geochemistry. Barringer Research Ltd., Rexdale, Ontario.

BUTT, C.R.M. AND ZEEGERS, H. (Editors), 1992. Regolith exploration geochemistry in tropical and subtropical terrains. Vol. 4: Handbook of Exploration Geochemistry, G.J.S. Govett (Editor). Elsevier Scientific Publ. Co., 607 pp.

CHAPPELL, W.R., ABERNATHY, C.O. AND CALDERON, R.L. (Editors), 1999. Arsenic exposure and health effects. Elsevier, Amsterdam, 416 pp.

DARNLEY, A.G., 1990. International geochemical mapping: a new global project. In: A.G. Darnley and R.G. Garrett (Editors), International Geochemical Mapping - IGCP Project 259. Special Issue, J. Geochem. Explor., 39: 1-13.

DARNLEY, A.G., 1995. International geochemical mapping - a review. J. Geochem. Explor., 55: 5-10.

DARNLEY, A.G., BJÖRKLUND, A., BøLVIKEN, B., GUSTAVSON, N., KOVAL, P.V., PLANT, J.A., STEENFELT, A., TAUCHID, M., XUEJING, X., GARRETT, R.G. AND HALL, G.E.M., 1995. A global geochemical database for environmental and resource management. UNESCO Publishing, Paris, 122 pp.

DAVIS, J.C., 1973. Statistics and data analysis in geology. J. Wiley \& Sons, Inc., N.Y., 550 pp.

DEMETRIADES, A., 1998. Global geochemical baselines: A fundamental international project for environmental management. Bull. Geol. Soc. Greece, XXXII(1): 321-329.

DEMETRIADES, A., STAVRAKIS, P. AND VERGOU-VICHOU, K., 1997. Exploration geochemistry in environmental impact assessment: Examples from Greece. In: P.G. Marinos, G.C. Koukis, G.C. Tsiambaos and G.C. Stournaras (Editors), Engineering Geology and the Environment. A.A. Balkema, Rotterdam, 2: 17571762 .

FAIRBRIDGE, R.W., 1972. The Encyclopedia of Geochemistry and Environmental Sciences. Van Nostrand Reinhold Co., N.Y., 1321 pp.

FERGUSSON, J.E., 1990. The heavy elements: Chemistry, environmental impact and health effects. Pergamon Press, Oxford, 614 pp.

FLETCHER, W.K. (Editor), 1981. Analytical methods in geochemical prospecting. Vol. 1: Handbook of Exploration Geochemistry, G.J.S. Govett (Editor). Elsevier Scientific Publ. Co., Amsterdam, 255 pp.

FLETCHER, W.K., HOFFMAN, S.J., MEHRTENS, M.B., SINCLAIR, A.J. AND THOMSON, I., 1986. Exploration geochemistry: Design and interpretation of soil surveys. Society of Economic Geologists, 180 pp.

GINZBURG, I.I., 1960. Principles of geochemical prospecting. Pergamon Press, London, 298 pp.

GOLDSCHMIDT, V.M., 1970. Geochemistry. Oxford University Press, 730 pp.

GOVETT, G.J.S., 1986. Geochemistry: Its achievements and potential in mineral exploration. In: I. Thornton and R.J. Howarth (Editors), Applied Geochemistry in the 1980s. Graham \& Trotman Ltd., London: 3-38.

GOVETT, G.J.S., 1983. Rock geochemistry in mineral exploration. Vol. 3: Handbook of Exploration Geochemistry, G.J.S. Govett (Editor). Elsevier Scientific Publ. Co., Amsterdam, 461 pp.

GREEN, P.M., KEYNON, J.R. AND BREWARD, N., 1997. Discovering geology: The Lake District. NERC, British Geological Survey, Keyworth, Nottingham, CD-rom.

GROSSMAN, J.N., 1998. National geochemical atlas: The geochemical landscape of the conterminous United States derived from stream sediment and other solid sample media analysed by the national uranium evaluation (NURE) program. U.S. Geol. Survey Open-File Report 98-622.

HALE, M. (Editor), 2000. Geochemical remote sensing of the sub-surface. Vol. 7: Handbook of Exploration Geochemistry, G.J.S. Govett (Editor). Elsevier Scientific Publ. Co., Amsterdam, 572 pp.

HALE, M. AND PLANT, J.A. (Editors), 1994. Drainage geochemistry. Vol. 6: Handbook of Exploration Geochemistry, G.J.S. Govett (Editor). Elsevier Scientific Publ. Co., Amsterdam, 766 pp.

HAWKES, H.E., 1957. Principles of geochemical prospecting. U.S.G.S. Bull. 1000-F: 225-355.

HAWKES, H.E., 1976. The early days of exploration geochemistry. J. Geochem. Explor., 6: 1-11.

HAWKES, H.E. AND WEBB, J.S., 1962. Geochemistry in mineral exploration. Harper \& Row, Publishers, N.Y., $415 \mathrm{pp}$.

HEMPHILL, D.H. AND COTHERN, C.R. (Editors), 1989. Trace substances in environmental health. Univer- 
sity of Missouri, $386 \mathrm{pp}$.

HOWARTH, R.J. (Editor), 1983. Statistics and data analysis in geochemical prospecting. Vol. 2: Handbook of Exploration Geochemistry, G.J.S. Govett (Editor). Elsevier Scientific Publ. Co., Amsterdam, 437 pp.

HUANG, C.I., 1991. Environmental monitor. Explore, The Association of Exploration Geochemists Newsletter, No. 70: 17.

JOYCE, A.S., 1976. Exploration geochemistry. Techsearch Inc. \& The Australian Mineral Foundation, 219 pp.

KAURANNE, L.K., SALMINEN, R. AND ERIKSSON, K. (Editors), 1992. Regolith exploration geochemistry in arctic and temperate terrains. Vol. 5: Handbook of Exploration Geochemistry, G.J.S. Govett (Editor). Elsevier Scientific Publ. Co., Amsterdam, 443 pp.

LEPELTIER, C., 1969. A simplified statistical treatment of geochemical data by graphical representation. Econ. Geol., 64: 538-550.

LERNER, D.N. AND WALTON, N.R.G. (Editors), 1998. Contaminated land and groundwater: Future directions. The Geological Society, London, $248 \mathrm{pp}$.

LEVINSON, A.A., 1974. Introduction to exploration geochemistry. Applied Publishing Ltd., Wilmette, Iilinois, 614 pp.

LEVINSON, A.A., 1980. Introduction to exploration geochemistry. Applied Publishing Ltd., Wilmette, Illinois, 924 pp.

LEVINSON, A.A., BRADSHAW, P.M.D. AND THOMSON, I., 1987. Practical problems in exploration geochemistry. Applied Publishing Ltd., Wilmette, Illinois, 269 pp.

MARSHALL, C.P. AND FAIRBRIDGE, R.W., 1999. Encyclopedia of Geochemistry. Kluwer Academic Publishers, Dordrecht, The Netherlands, 712 pp.

MASON, B., 1966. Principles of geochemistry. J. Wiley \& Sons, Inc., N.Y., 329 pp.

NLFB, 2000. Digitaler atlas Hintergrundwerte. Niedersächsisches Landesampt für Bodenforschung, Hannover.

PLANT, J.A., KLAVER, G., LOCUTURA, J., SALMINEN, R., VRANA, K. AND FORDYCE, F.M., 1996. Forum of European Geological Surveys (FOREGS) Geochemistry Task Group 1994-1996 Report. British Geological Survey, Keyworth, Technical Report WP/95/15, 52 pp.

PLANT, J.A., KLAVER, G., LOCUTURA, J., SALMINEN, R., VRANA, K. AND FORDYCE, F.M., 1997. The Forum of European Geological Surveys (FOREGS) Geochemistry Task Group inventory. J. Geochem. Explor., 59: $123-146$.

RANKAMA, K. AND SAHAMA, TH.G., 1950. Geochemistry. The University of Chicago Press, Chicago, 912 pp.

RATTIGAN, J., 1970. The geochemical prospecting programme. In: L.J. Lawrence (Editor), Exploration and Mining Geology with particular reference to the Commonwealth of Australia. Australian Inst. Min. Metall., 2: $72-81$.

ROSE, A.W., HAWKES, H.E. AND WEBB, J.S., 1979. Geochemistry in mineral exploration. Academic Press, London, $657 \mathrm{pp}$.

RUNNELLS, D.D., 1993. Application of exploration geochemistry tools to environmental purposes. Explore, The Association of Exploration Geochemists Newsletter, No. 78: 12-13.

SALMINEN, R., TARVAINEN, T., DEMETRIADES, A., DURIS, M., FORDYCE, F.M., GREGORAUSKIENE, V., KAHELIN, H., KIVISILlA, J., KLAVER, G., KLEIN, P., LARSON, J.O., LIS, J., LOCUTURA, J., MARSINA, K., MJARTANOVA, H., MOUVET, C., O’CONNOR, P., ODOR, L., OTTONELlO, G., PAUKOLA, T., PLANT, J.A., REIMANN, C., SCHERMANN, O., SIEWERS, U., STEENFELT, A., VAN DER SLUYS, J. AND WILLIAMS, L., 1998. FOREGS geochemical mapping manual. Guide 47, Geological Survey of Finland, Espoo, 42 pp.

SIEGEL, F.R., 1974. Applied geochemistry. J. Wiley \& Sons, N.Y., 353 pp.

SINCLAIR, A.J., 1974. Selection of threshold values in geochemical data using probability graphs. J. Geochem. Explor, 3: 129-149.

STANLEY, C.R., 1987. PROBLOT, An interactive computer program to fit mixtures of normal (or log normal) distributions with maximum likelihood optimisation procedures. Association of Exploration Geochemists, Nepean, Ontario.

STANTON, R.E., 1966. Rapid methods of trace analysis for geochemical applications. Edward Arnold (Publishers) Ltd., London, 96 pp.

STANTON, R.E., 1976. Analytical methods for use in geochemical exploration. Edward Arnold (Publishers) Ltd., London, 55 pp.

TENNANT, C.B. AND WHITE, M.L., 1959. Study of the distribution of some geochemical data. Econ. Geol., 
54: 1281-1290.

THORNTON, I. (Editor), 1983. Applied environmental geochemistry. Academic Press, London, 501 pp.

THORNTON, I. (Editor), 1988. Geochemistry and health. Science Reviews Ltd., Northwood, 272 pp.

THORNTON, I. AND CULBARD, E. (Editors), 1987. Lead in the home environment. Science Reviews Ltd., Northwood, 224 pp.

VERNADSKY, V.I., 1998. The Biosphere. Copernicus, N.Y., 192 pp.

WEBB, J.S., 1983. Foreword. In: I. Thornton (Editor), Applied environmental geochemistry. Academic Press, London: vii-viii.

WEBB, J.S., THORNTON, I., THOMPSON, M., HOWARTH, R.J. AND LOWENSTEIN, P.L., 1978. The Wolfson geochemical atlas of England and Wales. Clarendon Press, Oxford, $70 \mathrm{pp}$.

WEDEPOHL, K.H. (Exec. Editor), 1969-1978. Handbook of Geochemistry. Vol. I, II-1, II-2, II-3, II-4, II-5. Springer-Verlag, Berlin. 